\title{
Investigation of a
}

High-Density Tungsien-Base Alloy 
This report was prepared as an account of work sponsored by the United States Government. Neither the United States nor the United States Atomic Energy Commission, nor any of their employees, nor any of their contractors, subcontractors, or their employees, makes any warranty, express or implied, or assumes any legal liability or responsibility for the accuracy, completeness or usefulness of iny information, apparatus, product or process disclosed, or represents that its use would not infringe privataly owned rights.

This report, like other speciai-purpose documents in the LA. . .MS series, has not been reviewed or verified for accuracy in the interest of prompt distribution.

Printed in the United States of America. Available from National Technical Information Service

U. S. Department of Commerce

5285 Port Royal Road

Springfield, Virginia 22151

Price: Printed Copy \$3.00; Microfiche $\$ 0.95$ 
LA-4695-MS

UC-25

ISSUED: October 1971

os Lalamos

seientitic laboratory

of the Univorsity of California

LOS ALAMOS, NEW MEXICO 87544

1

\section{Investigation of a}

\section{High-Density Tungsten-Base Alloy}

by

H. Sheinberg

J. T. lirakes

R. E. Riley

NOTICE

Thls report was prepared as an account of work sponsored by the United States Government. Neither

the United States nor the United Stotes Atomic Eneny

Comminalon; nor any of thelr employees, nor any of

their contractors, subcontractors; or their employees,

makes any wurranty, express or implled, or asumes any

lom liebility or responsibifity for the iccuracy, com-

pletongs or usefulness of any information, appiratus,

product or process disclosed, or represonts that its use

would not infringe privately owned rights. 
INVESTIGATION OF A HIGH-TSENSITY TUIGSTEN-EASE ALWO

by

H. Sheinbers, J. T. Frakes, and R. E. Riley

ABS'SRACT

\begin{abstract}
The effect of sintering time, temperature and atmosphere, postsintering heat treatornth, tungaten particle size, and compositional varlations upon the sechanical properties and structure of a $95 \mathrm{wt} \% \mathrm{W-3} .5$ wt\% $\mathrm{N1-1.5}$ wt\% Fe buse alloy were Investigated. Improvements were observed with postaincering heat treatments, fine tungsten powders, and small rhentum or ciaromium additions.
\end{abstract}

\section{TMRRODUCTION}

The 95 wt. $W-3.5$ wt $11-3.5$ wt $\$$ Fe alloy Invest1gated in this program comprised gratns of tungsten distributed in a matrix phase of W-N1-Fe formed when the inftial binder phise, N1-Fe, takes tungsten into solution from the dispersed tungaten grains. We attempted to undexstarid the effects of initial tungsten powder size, sintering and heat-treatment scheciules, ctmosphere, and. binder additives upon the tensile properties and ductility of this hydrostatically pressed ans sintered material, and to attempt to correlute these effects with observed microstructurs.

Variations in inftial particle size and in sintering and heat..treatioent schedules rere antic1pated to exhibit an effect upon the density, grain size, and dissolution of tungyten into the binder phase. The differences in atwopheres were expected to reveal the effect of hydrogen embrittlement in the alloy. Finally, the use of varlous additives was expected to affect the diatribution and strength of the binder phase and, poasibly, the ductility of the tungeten grains.

\section{RAN MATHIAIS}

Four lots of tungaten powders, three lots of nickel, and one lot of iron powder were used in this Invectigation. The chemical analyeed of these powdere are recorded in lable I and the general powder characteristice are shom in Twble II. A brief explanation of powder characterization is given In Sec. IV. Lots $W-44,155$, and 164 are hydrogen reduced tungsten posders. The caminercial nickel powdera were all prepared by aecomposition of $\mathrm{N1}(\mathrm{CO})_{4}$ and the Iron wes also a carionyl type powder.

The microstructure of representative tungsten, Iron, and nickel powderis fis shown in FIgs. 1 and 2 , and the particle-size distributions are presented In Figa. 3 and 4.

\section{SAIPLI PREPARATION}

The porders deacribed prevlously were used in the as-recelved sondition. For the three principal blends of the staniard coupoition euployling coarse, Intermediate, and fine tungsten powde:s, the tungsten wes welghed to $\pm 1 \mathrm{~g}$ and the nickel and iron to $\pm 0.1 \mathrm{~g}$. The welghts of these blends were 59.0 , 18.2 , and $12.0 \mathrm{~kg}$, respect1vely; the largest was blended in a $N_{2}$ atwosphare in a 1-rt capacity Fattersor-Kelley twin ahell blender for $14 \mathrm{~b}$. The other two lots were aimflarly blended in an 8-qt Fetterion-Kelley twin shell blender. Whm.. aml (1500-B) charges were exployed to study compositional variations, the tungaten wa weighed to $\pm 0.01 \mathrm{~g}$. These charges were blended in inert atworphere in cotating pint bottles equipped with alunimu af!tator wires. The botiles revolved at $60 \mathrm{rm}$ for $14 \mathrm{~h}$. In propering rodu to ba machined into temeile epecimens, blended powders vere poured into $7 / 8-1 n$. 1.d. 
TABLE I

CHEMICAL ANALYSES OF POWDERS ${ }^{2}$

\begin{tabular}{|c|c|c|c|c|c|c|c|}
\hline $\begin{array}{l}\text { Powder Lot } \\
\text { Element }\end{array}$ & $\begin{array}{l}\mathrm{Ni}-21 \\
\text { DED }\end{array}$ & $\begin{array}{c}\mathrm{Ni-23} \\
\text { ppon }\end{array}$ & $\begin{array}{l}\mathrm{Ni}-24 \\
\text { gpon }\end{array}$ & $\begin{array}{c}\mathrm{Fe}-31 \\
\mathrm{ppm}\end{array}$ & $\begin{array}{l}W-44 \\
\text { ppm }\end{array}$ & $\begin{array}{c}\text { W-155 } \\
\text { ppm }\end{array}$ & $\begin{array}{l}\text { W-164 } \\
\text { DppiI }\end{array}$ \\
\hline$L i$ & $<4$ & $<4$ & $<4$ & $<10$ & & $<1$ & $<3$ \\
\hline $\mathrm{Be}$ & $<4$ & $<4$ & $<4$ & $<10$ & $<10$ & $<1$ & $<1$ \\
\hline$B$ & $<10$ & $<10$ & $<10$ & $<100$ & $<10$ & $<3$ & $<3$ \\
\hline $\mathrm{Ne}$ & $<4$ & $<$ & $<4$ & $<30$ & N.D. & $<3$ & $<3$ \\
\hline $\mathrm{Mg}$ & $<1$ & $<1$ & $<1$ & $<3$ & 30 & $<1$ & $<1$ \\
\hline AI & $<8$ & $<8$ & $<8$ & $<10$ & $<10$ & $<10$ & $<10$ \\
\hline S1 & $<8$ & $<8$ & $<8$ & $<3$ & 100 & $<10$ & $<10$ \\
\hline $\mathbf{K}$ & $<20$ & $<20$ & $<20$ & $<30$ & & $<10$ & 100 \\
\hline $\mathrm{Ca}$ & $<1$ & $<1$ & $<1$ & $<10$ & N.D. & $<3$ & 10 \\
\hline $\mathrm{T1}$ & $<8$ & $<8$ & $<8$ & $<10$ & $<100$ & $<30$ & $\begin{array}{l}<30 \\
<30\end{array}$ \\
\hline $\begin{array}{l}\mathrm{V} \\
\mathrm{Cr}\end{array}$ & $\begin{array}{r}<10 \\
<4\end{array}$ & $\begin{array}{l}<<4 \\
<4\end{array}$ & $\begin{array}{r}<10 \\
<4\end{array}$ & $\begin{array}{r}<30 \\
10\end{array}$ & $\begin{array}{r}<100 \\
10\end{array}$ & $\begin{array}{l}<10 \\
<10\end{array}$ & $\begin{array}{l}<10 \\
<10\end{array}$ \\
\hline $\begin{array}{l}M_{n} \\
M_{n}\end{array}$ & $\begin{array}{l}<4 \\
<4\end{array}$ & $<4$ & $<4$ & $<3$ & 10 & $<3$ & $<3$ \\
\hline $\mathrm{Fe}$ & 10 & 10 & 10 & & 100 & $<3$ & 10 \\
\hline Co & $<40$ & $<40$ & $<40$ & $<10$ & $<100$ & $<10$ & $<10$ \\
\hline $\mathrm{Ni}$ & & & & 100 & 300 & $<10$ & $<10$ \\
\hline $\mathrm{Cu}$ & $<4$ & $<4$ & & $<10$ & $<10$ & $<3$ & $<1$ \\
\hline $\mathrm{Zn}$ & $<100$ & $<100$ & $<100$ & $<100$ & $<100$ & $<300$ & $<+2$ \\
\hline $\mathrm{Sr}$ & $<8$ & $<8$ & $<8$ & $<10$ & & $<10$ & $<10$ \\
\hline sto & & & & & $<300$ & $<300$ & $<300$ \\
\hline Mo & $<20$ & $<20$ & $<20$ & $<100$ & 100 & $<100$ & $<100$ \\
\hline $\mathrm{Ag}$ & $<1$ & $<1$ & $<1$ & & $<10$ & $<3$ & 3 \\
\hline $\mathrm{Cd}$ & $<80$ & $<80$ & $<80$ & $<10$ & & & \\
\hline $\mathrm{Sa}$ & $<20$ & $<20$ & $<20$ & $<30$ & $<10$ & $<10$ & $<10$ \\
\hline $\mathrm{Ba}$ & $<8$ & $<8$ & $<8$ & $<10$ & & $<3$ & $<3$ \\
\hline $\begin{array}{l}\mathrm{Pb} \\
\mathrm{Bi}\end{array}$ & $\begin{array}{l}<8 \\
<8\end{array}$ & $\begin{array}{l}<8 \\
<8\end{array}$ & $\begin{array}{l}<8 \\
<8\end{array}$ & $\begin{array}{l}<30 \\
<30\end{array}$ & $<10$ & $\begin{array}{l}<10 \\
<10\end{array}$ & $\begin{array}{l}<10 \\
<10\end{array}$ \\
\hline $\mathrm{Ta}$ & & & & & $<300$ & & \\
\hline $\mathrm{zr}$ & & & & & $<100$ & $<30$ & $<30$ \\
\hline
\end{tabular}

Where values are not reported, no deterninations were made.

TABLE II

FOWDER CHARACTTRISTICS

H1-21 \$1-23 N1-24 Fe-31 W-44 W-155 W-164

\begin{tabular}{|c|c|c|c|c|c|c|c|}
\hline Bulk density $\left(\rho_{B}\right) \mathrm{as} / \mathrm{cm}^{3}$ & 1.07 & 2.43 & 2.28 & 2.41 & 4.54 & 4.01 & 7.58 \\
\hline Tap derse1ty $\left(\rho_{\mathrm{T}}\right)_{\mathrm{B}}^{\mathrm{B}} / \mathrm{cm}^{3}$ & 1.59 & 3.43 & 3.68 & 3.56 & 6.59 & 5.84 & 10.32 \\
\hline$\rho_{T} / \rho_{B}$ & 1.48 & 1.41. & 1.61 & 1.52 & 1.45 & 1.45 & 1.33 \\
\hline Surface aree $\mathrm{m}^{2} / \mathrm{B}$, BET & 0.85 & 0.94 & 0.50 & - & 0.62 & 0.78 & 0.12 \\
\hline is av particle aize, $\mu \mathrm{m}$ & 1.7 & 3.9 & 2.5 & 4.4 & 3.8 & 1.7 & 9.1 \\
\hline $\begin{array}{l}\text { edian particle } \\
\text { Sedibal, } \mu \mathrm{m}\end{array}$ & 10.3 & 6.8 & 9.2 & 7.3 & 4.5 & 2.8 & 10.0 \\
\hline
\end{tabular}

plastisol (polyvinyl chloride) sacks and jolted lightly to a powder helght of $\sim 5-1 / 2$ in. A plest1sol $11 d$ was inserted on top of the powder and sealed to the sack with a liqued wolvent conalating of pjestieol diasolved in a 50-50 mixture of acetone and methylethyl ketone. The anme procedure was uned to load and seal 2-in. 1.d. encke to preas cylindere Por machining flexure specimens. Sacks were pleced in tight fitting perforated micarte sleeves (to ensure relatively stralght pressings) and then were placed in a perforated metal basket and hydrostat 1cally pressed at 50,000 psi in a 12-1n. 1.d. cham. ber. Preasing time was approximately $20 \mathrm{mln}$. Preased cylinders were removed from the sacks and scribed to maintain Ident1ty during subsequent sintering.

A 0.03-1n. -thick walled tungeten can (2.3 In. o.d. 7.0 in. long), with a porforated botton to 


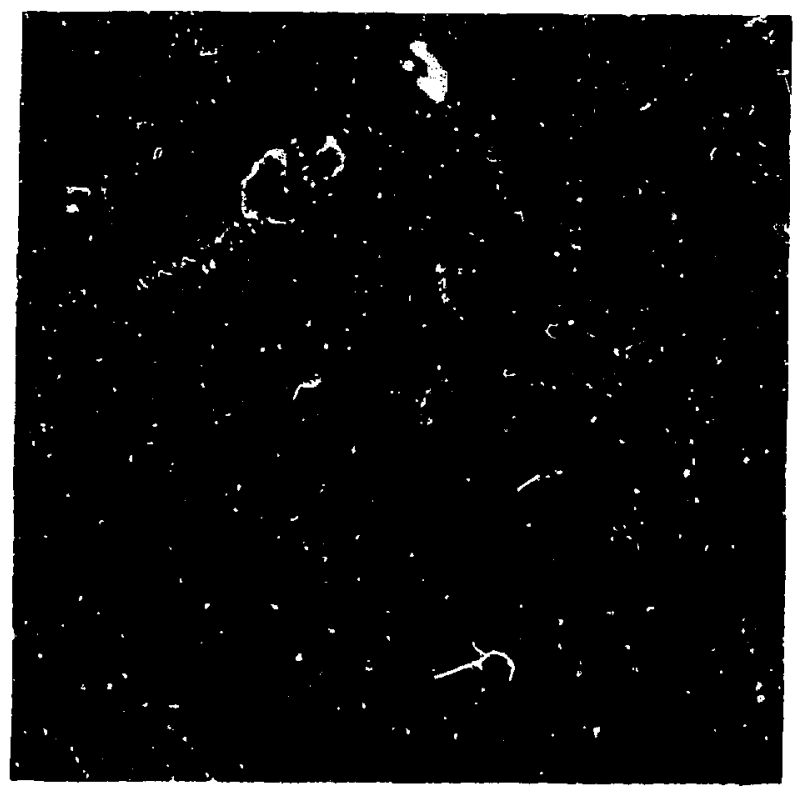

$250 x$
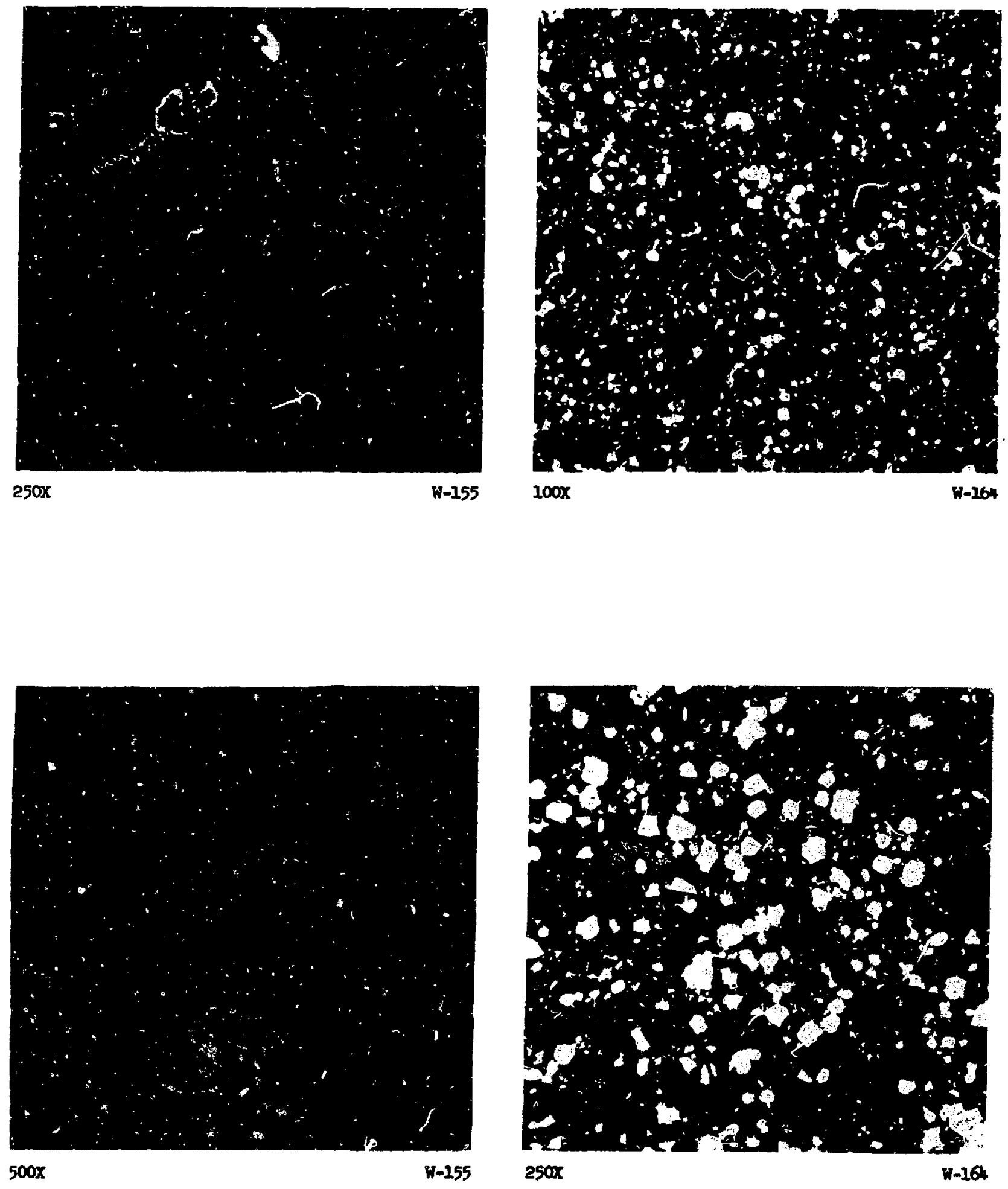

FI8. 1. Herostructure c: tungeten ponders. 


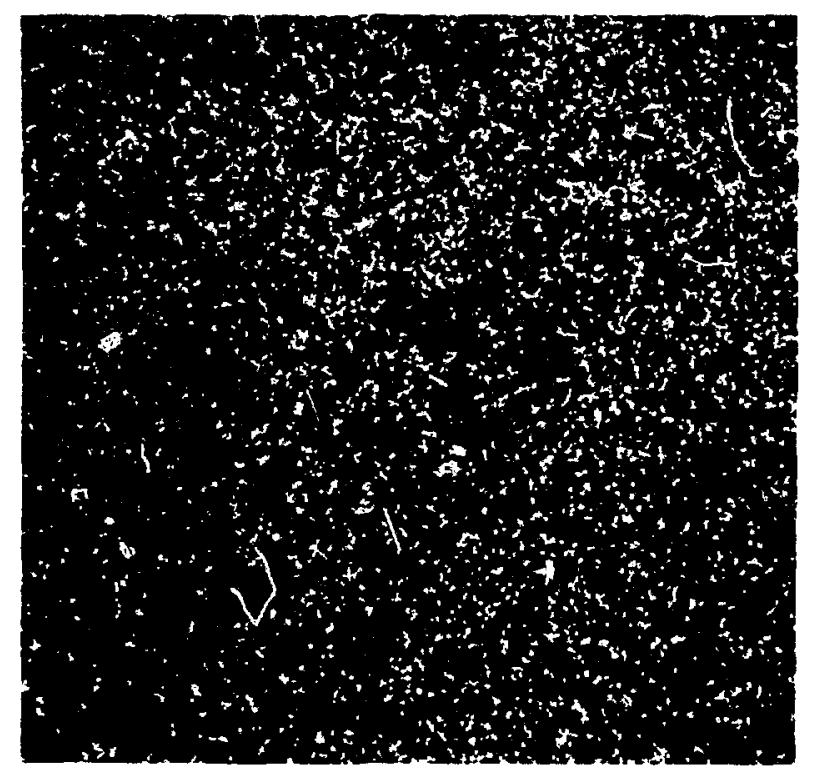

$100 x$

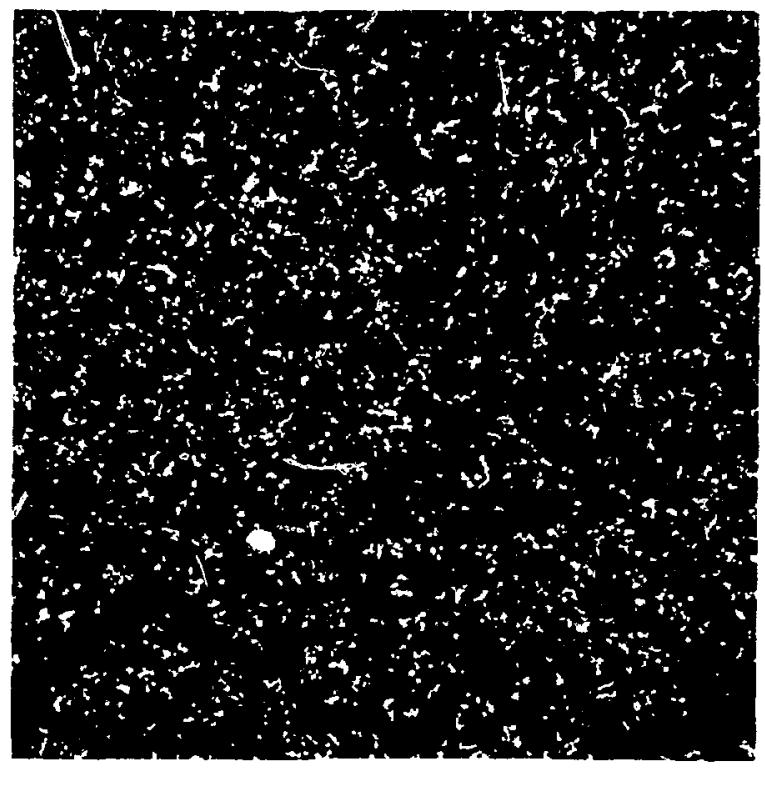

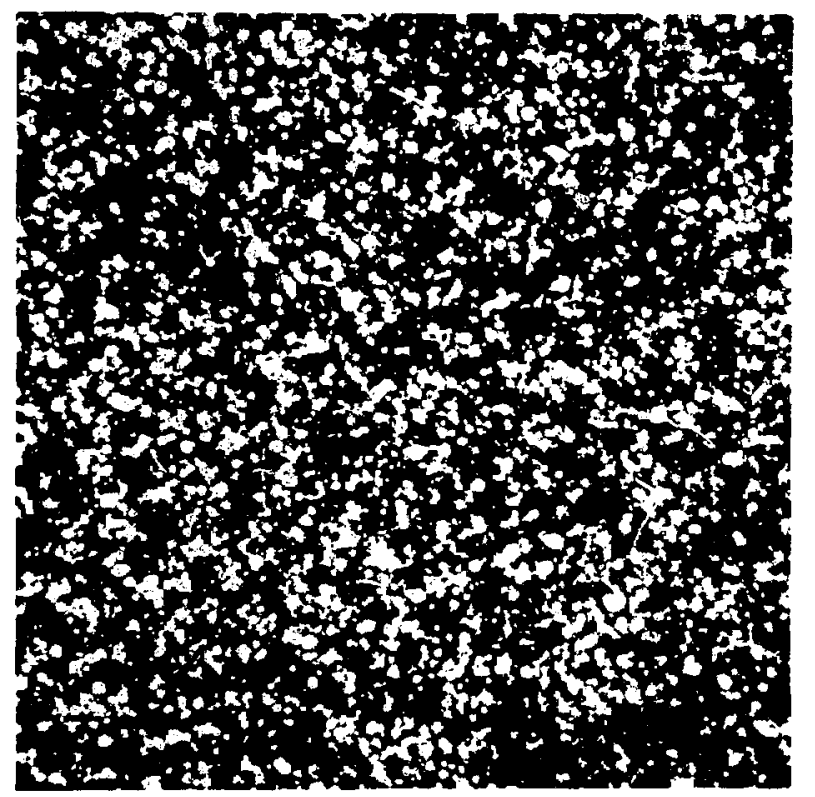
$250 x$

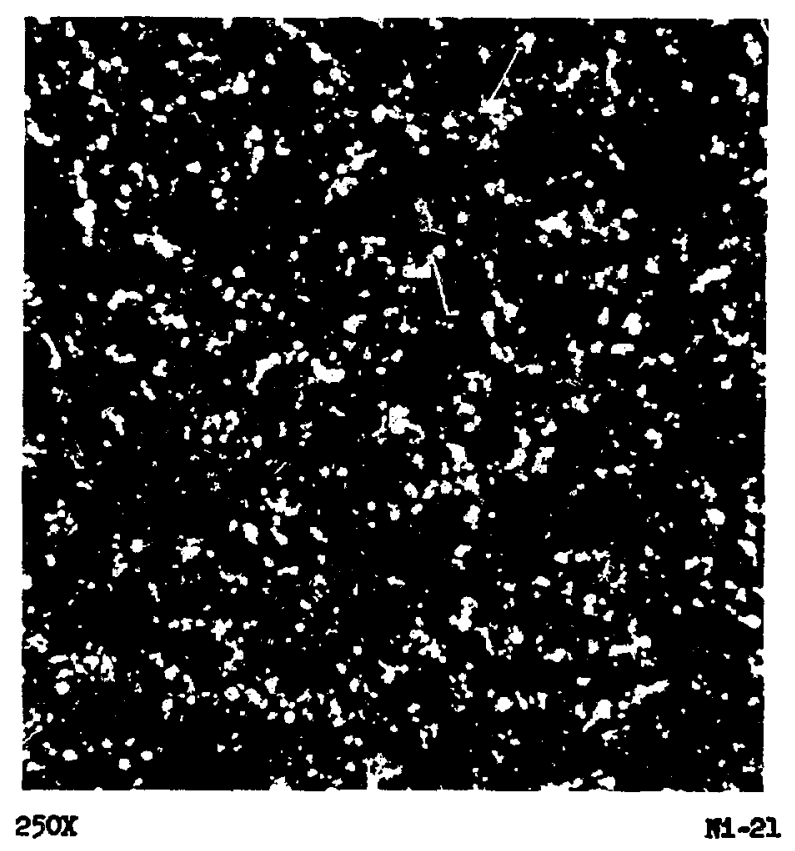

Fig. 2. Microstructure of Iron and nickel poiders. 


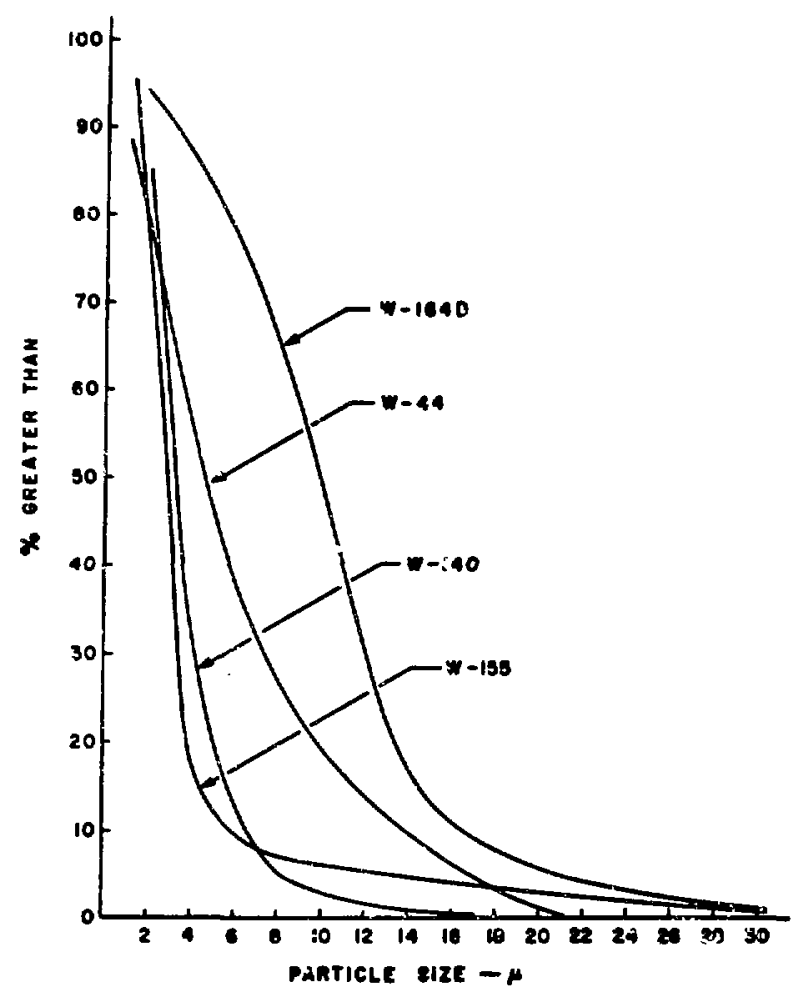

Fig. j. Particle-size distributions of tungsten powders.

allow for gas flow, was used for sintering the alloy presaings. A porous $\mathrm{A}_{2} \mathrm{O}_{3}$ disk, 3/8-in. thick, coyered the perforated botton and supported the pressings that were surrounded $t y$ and covered with -60 mesh $\mathrm{M}_{2} \mathrm{O}_{3}$. A callbrated $\mathrm{W}-(W-\mathrm{Re})$ thermocoupie was inserted into the $\mathrm{Al}_{2} \mathrm{O}_{3}$ adjacent to the preasings to monftor temperature. The can was centered verticully in the 3.0 in. $1 . \hat{G}$. by 20.0 in. Iong resiatance heated tungaten tube of a fumace manufactured by Ceneral blectric.

The stands $-i$ sintering cycle consisted of heatIng in hydrogen to $1300^{\circ} \mathrm{C}$ in $120 \mathrm{~min}$, holding at $1300^{\circ} \mathrm{C}$ for $120 \mathrm{~min}$, heating to $1520^{\circ} \mathrm{C}$ (or other dea Igneted temperature; In $30 \mathrm{~min}$, and rolding at $1520^{\circ} \mathrm{C}$ for $60 \mathrm{~min}$. The furnace wa coolad to $1200^{\circ} \mathrm{C}$ in 20 $\mathrm{m} . \mathrm{n}$ and held at that temperature for $20 \mathrm{~min}$ wile the atmosphere was changed to argon. Finally, the power was turned of and the rurnace tube was cooled In an argon atmosphere.

After unlowilng, impersion denultiee vere culculated on the plecen to check the degree of interIng. These numbers were for information only and are not subultted as dats.

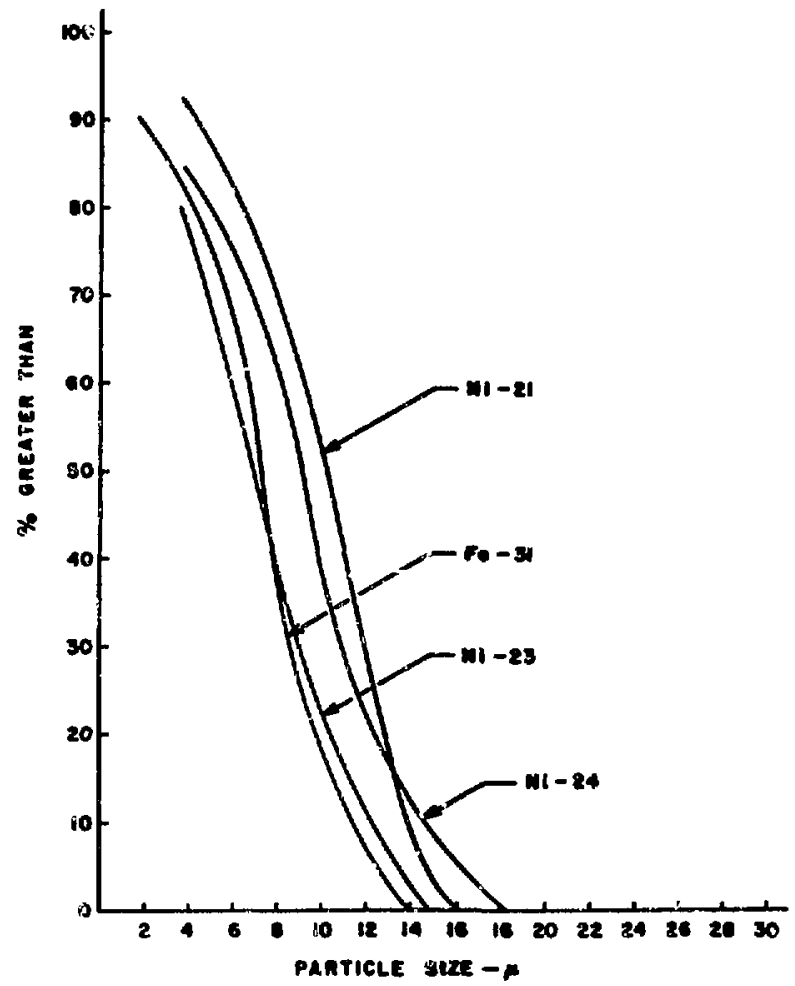

Fig. 4. Particle-size distribution of lion and nickel pounders.

The pressings were machined to right cylinders, cut to length, and center holes were drilled in both ends of each spectren. The cylinders were then turned to $6.43,5 \mathrm{In}$. dian whth a Keangaetal grade 907 carbide tool; $0,02-1 \mathrm{n}$. cuts were taken on the radius. A proprietary 1fquid, Tap Maglc, diluted with conventional cutting oil, was used to facilitata sachining. The specimens were then achinsd (using $0 . c e-I n$. cuts) with s tracer terpate arrangesent to within $90.020 \mathrm{In}$. of the IInished diametric dimensione of a standard $1 / 4-1 n$. tenalle specimen with i,0-1n. gesuge length (ASTH 188-66, p. 207, FIg. 8). The final tracer cuts were only 0.005 In. Uniflod $7 / 16-14$ threade were ground on eech end.

Grinding to the required dirensions and spec1fled 16-rm fintion in the rodused section wa accosplished with an 80-grit sdificon carbids weel turning at 3400 rm according to tine following achedule:

First pase: $0.001-1 \mathrm{n}$. mximing

second gase: $0.001-1 n$. nexdinim

Intird paes: $0.0005-1 \mathrm{n}$. vaxdimin to eperk. 
Simcool pray diluted abovt 40 to 1 was lised as the frinding coolant. The opecimens were inspected for complete compllance to ASTM and finiah apecifications. Close control over machining eliminated, as much as poseibje, varietions in this operation that concelvably could mask effects of intentionally introduced variables.

IV. TESTING FROCEDURES

\section{A. Powder Characterization}

The average particle size of powders was determined in accordance with ASTM Dealgmation B 330-58, "Average Size of Refractory Metals and Compounds by Flsher Sub-Sleve Sizer (FSS)." The mothod is designed to measure the specific surface area of a powder by determination of resistance, to fluid flow through a packed colum of powder aud subsequent caxculation of powder size from these values. The equijment includes an air pump, pressure regulator, presision manometer, precision calibrated sample tube, and a calculator chart for direct observation of average pariticle gize.

Masurement of the bulk or apparent density $\left(\rho_{B}\right)$ was made according to ASTM designation B-329-6I, "Apparent Density of Refractory Metals and Compounds by the scott volumeter." A brass funnel and metal sereen directs powder into a glass baffle box with two wooden sides and a funnel at the base of the box directs powder into an accurately sized ( 1.00 in. ${ }^{3}$ ) and tared denslty cup.

Tap density was determined by filing an acsurately tared $10 \mathrm{~cm}$ greduate with powder and tapping the graduate with a plestlc rod unt1l no further reduction in volume was observed with continued tapping. The quotient, powder veight/minimum volume, is the tap density.

Particle-size distribution was derived from sedimentation date obtained with a continuousiy recording sedimentation balance. The powder specimen 1. diopersed in a 50-50 ethylene glycol-distilled water solution and allored to settle; a time-cumulative welght record allows application of Stokes Ian for caleulation of cumuletive relght percent ve particle size.

The surface area of the powdere wa determined by uling a thuoc Model AFA-2 adsorption flow apparatus to measure the volume of $\mathrm{N}_{2}$ gas ragulyed to form a monolecular layer on the opecimen surface at 11quid $\mathrm{H}_{2}$ teiperature.

\section{B. Semple riepting}

Nechanical tesing was performed on an Instron testing machine ut1lizing a crosshead speed of $0.005 \mathrm{in.} / \mathrm{min}$. The tensile strength was the maximum load carried during the tension test divided by the original cross-sectional area of the specimen. The yleld strength was based on a $0.2 \%$ offset from the approximate modulus. Th1s approximate modulus was based on the best straight line drawn tangent at the origin of a curve traced from signals from a 1-In. gauge length strain gauge extensometer and losd values. Because the extensometer was not an averaging type, the values were not too accurate, and were used only as a bese for yleld etrength calculations. Elongation was determined by measurIng the geuge length after fracture and by couparing this value to the original gauge length, expressed as a percent increase in length (ASTM E-8-66).

The procedure for estimating grain size was essentially the mensuration procedure described as one of the ASTM standard methods for estirating the everage grain size of metal. (ASTM E 112-6:3). Fhotomicrographs of a representative field of the test specimen were compared to standard grain size charts and the value of grain size most closely resembling the teat apecimen was chosen.

The hardness determination method is described In ASTM E 92-67, and is a Vicke:s hardiness obtsined by uaing a diamond indenter and evaluation of its impression after forcing this indenter under a predeteriained load into the surface of the material being tested.

Density values were computed by applying immersion techniques to machined tensile and flexure specimens.

\section{v. DISCUSSTON OF IESULTS}

The process of densification belleved to occur In these tungsten alloys was described by Krock; ${ }^{1}$ 1t proceeds first in the solid state and later as 11quid-phsse alntering when the temperature reaches a sufficlent level. In the standerd sintering schedule used in this investigat,ion (Table III, footnote c), the solid-state sintering occurred primarily during the $2-\mathrm{h}$ hold at $1300^{\circ} \mathrm{C}$. This solldstate intering comprised initial solution of tungsten Into the M1-Fe matrix phase followed by tungaten difriation through the W-N1-Fe boundary or through the N1-Fe phase. Th1s transport is 
TABLS III

BAYPLE DESCRTPJICRS

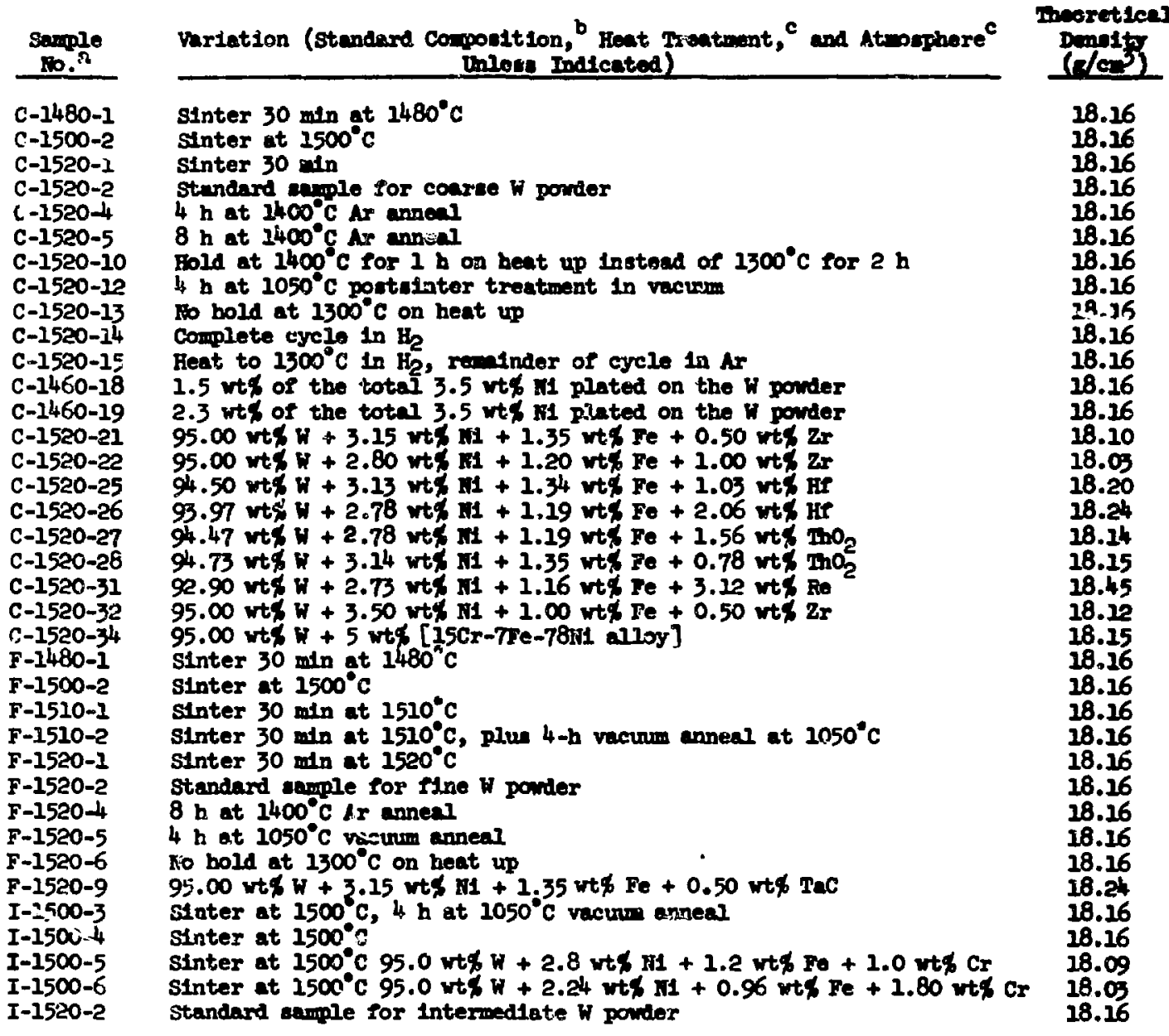

\footnotetext{
a The letter prefix to the aample muber indicates the alze of tungaten ponder used in the sample; C, F, and I denote coarae, IIne, and Internedlate powder, respectively. The fourdigit mmiter following the letter indicates the alntering tenperature used. The final muber of the three-part designation ia merely a apecimen designation muber.

${ }^{b}$ Standard composition was 95.0 wt $\% \mathrm{w}+3.5 \mathrm{wt \%} \mathrm{NI}+1.5 \mathrm{wt} \% \mathrm{Fe}$.

${ }^{c}$ Standard hat-treatment schedule und atmonphere was as follows: heat to $1300^{\circ} \mathrm{C}$ in $\mathrm{HS}$ in about $2 \mathrm{~h}$; hild for $2 \mathrm{~h}$; heat to $1520^{\circ} \mathrm{C}$ In $30 \mathrm{~min}$; hald $1 . \mathrm{h}$; cool to $1200^{\circ} \mathrm{C}$ in $20^{\circ}$ min; hold for 20 min while changing to argon atmosphere; and fins $12 \mathrm{v}$, turn orf power and cool in argon.
}

apparently an activated process whereln nickel accelerates the movement of tungaten by creating lower energy transport paths. Growth of the diapersed particles occurs by particle agglomeration preceding volume iffusion of tungten. The higher melting point of the tungaten componant is taken into solution in the liquid phese, in transported by volume diffuaion, and 18 reprecipitated onto solld particles of the higher melting phase.
Descriptions of the various sappies tested are given in Table III. These samples incorporated varlations in tungtten particle size, sintering schedule, atmouphere, annealing, and comostionn addtives. Goreral and specirlc observations wre ade with respect to these variables and are prosented below. Table IV presents the properties deterinod for the variou apecimen, and in nont ceses the mubere procented are avernges of three raluse. The 
TABIS IV

PROPGRTES OF W-N1-Fe RASE AHLYS

\begin{tabular}{|c|c|c|c|c|c|c|c|c|}
\hline $\begin{array}{l}\text { Sample } \\
\text { No. }\end{array}$ & $\begin{array}{l}\text { Tensile Strength } \\
(0 \mathrm{~g} 1 \times 1000)\end{array}$ & $\begin{array}{l}\text { Yleld strength } \\
\text { (ps1 } \times 1000)\end{array}$ & $\begin{array}{l}\text { Elongation } \\
\text { (\%) }\end{array}$ & $\begin{array}{c}\text { Nodulus } \\
\left(\text { psi } \times 10^{6}\right) \\
\end{array}$ & $\begin{array}{l}\text { Grain Size } \\
\text { (Av D1am mm) }\end{array}$ & $\begin{array}{l}\text { Hardness } \\
\text { (dph) }\end{array}$ & $\begin{array}{l}\text { Dens: } \\
\text { (g/Cm? }\end{array}$ & ty \\
\hline $\begin{array}{l}C-1480-1 \\
C-1500-2 \\
C-1520-1 \\
C-1520-2 \\
C-1520-4 \\
C-1520-5 \\
C-1520--9 \\
C-1520-12 \\
C-1520-13 \\
C-1520-14 \\
C-1520-15 \\
C-1460-18 \\
C-1460-19 \\
C-1520-21 \\
C-1520-22 \\
C-1520-25 \\
C-1520-26 \\
C-1520-27 \\
C-1520-28 \\
C-1520-31 \\
C-1520-32 \\
C-1520-34 \\
F-1480-1 \\
F-1500-2 \\
F-1510-1 \\
F-1510-2 \\
F-1520-1 \\
F-1520-2 \\
F-1520-4 \\
F-1520-5 \\
F-1520-6 \\
F-1520-9 \\
I-1500-3 \\
I-1500-4 \\
I-1500-5 \\
I-1500-6 \\
I-1520-2\end{array}$ & $\begin{array}{c}(A) \\
(A) \\
94.0 \\
124.8 \\
124.2 \\
128.5 \\
124.6 \\
123.6 \\
100.0 \\
106.2 \\
121.0 \\
96.3 \\
96.3 \\
89.6 \\
83.7 \\
97.5 \\
80.0 \\
103.0 \\
77.9 \\
128.4 \\
83.9 \\
(A) \\
(A) \\
103.4 \\
133.0 \\
123.5 \\
130.8 \\
123.2 \\
124.9 \\
116.1 \\
99.3 \\
97.4 \\
90.8 \\
107.3 \\
124.3 \\
94.4\end{array}$ & $\begin{array}{l}(A) \\
(A) \\
83.1 \\
86.0 \\
84.0 \\
85.6 \\
81.0 \\
84.6 \\
85.4 \\
76.6 \\
78.4 \\
95.5 \\
95.7 \\
71.4 \\
70.3 \\
74.5 \\
69.9 \\
75.0 \\
78.5 \\
122.5 \\
79.1 \\
(A) \\
(A) \\
87.6 \\
92.2 \\
87.7 \\
86.3 \\
84.2 \\
86.9 \\
88.4 \\
85.4 \\
81.1 \\
82.1 \\
78.6 \\
92.2 \\
83.0\end{array}$ & $\begin{array}{r}(A) \\
(A) \\
2.3 \\
8.5 \\
11.5 \\
17.0 \\
18.0 \\
12.0 \\
3.0 \\
8.0 \\
17.3 \\
2.0 \\
2.0 \\
3.3 \\
2.0 \\
3.0 \\
1.3 \\
6.3 \\
<.0 \\
1.3 \\
2.0 \\
(A) \\
(A) \\
3.0 \\
25.0 \\
11.3 \\
26.7 \\
16.7 \\
25.3 \\
7.0 \\
3.0 \\
2.0 \\
2.0 \\
4.3 \\
2.0 \\
4.0\end{array}$ & $\begin{array}{l}41.8 \\
(A) \\
43.0 \\
35.2 \\
54.0 \\
37.6 \\
36.7 \\
56.0 \\
42.4 \\
39.8 \\
37.5 \\
41.8 \\
39.1 \\
35.4 \\
34.3 \\
37.7 \\
69.2 \\
45.3 \\
49.6 \\
37.6 \\
57.9 \\
38.2 \\
35.9 \\
36.0 \\
74.7 \\
53.2 \\
38.0 \\
41.5 \\
41.0 \\
37.3 \\
56.9 \\
43.5 \\
40.8 \\
65.6 \\
41.8 \\
42.0\end{array}$ & $\begin{array}{l}0.011 \\
0.011 \\
0.025 \\
0.045 \\
0.045 \\
0.045 \\
0.038 \\
0.045 \\
0.032 \\
0.053 \\
0.038 \\
0.053 \\
0.053 \\
0.038 \\
0.035 \\
0.032 \\
0.032 \\
0.032 \\
0.038 \\
0.019 \\
0.053 \\
0.064 \\
0.027 \\
0.013 \\
0.032 \\
0.027 \\
0.032 \\
0.035 \\
0.045 \\
0.050 \\
0.027 \\
0.045 \\
0.032 \\
0.022 \\
0.053\end{array}$ & $\begin{array}{l}150 \\
165 \\
280 \\
310 \\
320 \\
315 \\
295 \\
310 \\
315 \\
265 \\
275 \\
315 \\
310 \\
250 \\
275 \\
275 \\
240 \\
280 \\
275 \\
400 \\
325 \\
305 \\
315 \\
310 \\
310 \\
315 \\
320 \\
315 \\
320 \\
315 \\
325\end{array}$ & $\begin{array}{l}16.94 \\
16.03 \\
17.83 \\
18.03 \\
17.91 \\
18.15 \\
18.14 \\
17.98 \\
18.04 \\
18.07 \\
17.68 \\
18.05 \\
18.09 \\
16.98 \\
16.80 \\
17.49 \\
17.12 \\
17.39 \\
17.50 \\
18.42 \\
17.66 \\
17.76 \\
17.79 \\
17.29 \\
18.10 \\
18.01 \\
17.95 \\
18.03 \\
18.16 \\
18.03 \\
18.03 \\
17.99 \\
18.03 \\
17.92 \\
17.65 \\
17.69 \\
18.13\end{array}$ & $\begin{array}{c}93.28 \\
88.27 \\
98.18 \\
99.28 \\
98.62 \\
99.94 \\
99.89 \\
99.01 \\
99.34 \\
99.50 \\
97.36 \\
99.39 \\
99.61 \\
93.81 \\
93.18 \\
96.10 \\
93.86 \\
95.87 \\
96.42 \\
99.84 \\
97.46 \\
97.85 \\
97.96 \\
95.21 \\
99.67 \\
99.17 \\
98.84 \\
99.28 \\
100.00 \\
99.28 \\
99.28 \\
98.57 \\
99.28 \\
98.68 \\
97.57 \\
98.11 \\
99.83\end{array}$ \\
\hline
\end{tabular}

(A) Fallure occurred in threado of sample.

average deviation for these values was about $\pm 3 \%$. Many sequential number are absent from both Table III and Table IV. Shny more samples were made and scribed with numbers than were tested. Early results with sintering schedules and sintering atwosphere studise obviated the need for some previously anticipated investigations. Some cumples mubered beforehand and eselgned to specifle Investigations were not uned and, therefore, were calfted fran the tables. An mentloned prevlously, rlescure test spec1wens were prepared. After a few tests, bowever, it becane obvious that this material was too ductile to furnish neaningrul values of Ilexure strength and this phase of testing was discontinued.
As aeen from the porder characteristics discusaed in Sec. II, three general size ranges of tungsten powder were used in this study. There was fine $(1.7 \mu \mathrm{m})$, Intermediate $(3.8 \mu \mathrm{m})$, and coarse tungsten $(9.1 \mu \mathrm{m})$. The nickel powders used have also been $U E E$ ribed prevlously. Three lots of nickel powder were used with the tungsten powders due to limitations of avallable quantities. An effort wa made to choose these nickel poinders so that they would be as afmilar as posetble. No property variationa were attributed to variations in the nicked powders. The green or as-preased atrength wa detervined for anplea of both the fine and coarse tungeten batches of standard 95 wt\$ $\mathrm{W:}$ 3.5 wtis $\mathrm{N1}: 1.5$ wt/ Fe crmposition. These values, 
as determined by fleonire teating, were 1220 and 750 pai, respectively, Wetellography of the coarte and fine atandards in the green otate is ohown in Mg. 5.

Tungaten alloy, prepared by liquid phase alntering, Benerally exchibit a characteristic microetructure such as sample C-1520-2 (F1G. 6), which consiste of rounded particles of tungeten dispersed In a W-NI-Fe metrix. This microstructure is sionificantly different from thet of sarple C-1480-1 (F18. 6), which 1o of the sane couposition intered under an 1dentical achechule except that it had a intering temperature of $1480^{\circ} \mathrm{C}$ rather than $1520^{\circ} \mathrm{C}$. This teroperature was too low to effect ignificant I1quid phase sintering. The metallography of standard samples prepared with coarse, fine, and interwodlete tungsten powders are presented as sample c-1520-2 (F18. 6), F-1520-2 (F1g. 7), and I-1500-4 (F16. 8), respectively. In general, with opecinen, differing only in the Initiel particle alze of the tungaten powder, sauples rabricated with the finer tungaten showed better strength and elongation. Near-theoretical density was attainable at oborter times and lower temperatures than required for mo conrse pouders (sauple F-1510-1, F1G. 9).

In analyzins the effects of variations in sintering conditions, the following concluslons vere drawn. (a) At a given sintering time, increases in temperature up to an optimm for denalficstion led to increases in ultimate tenalle atrongth, elongation, and grain alze for all initial tungaten powder sizes utilised. (b) At a glvon alntering teuperature, increases in sintering tinc ylelded increased ultimate tenalle strength, elongation, end grain size up to the point where excessive grain growth became counterproductive. Innufficient alntering times and teuperature produced nateriale of unaultable atructures (cample c-1460-1, F1g. 6, and angle F-1500-2, F1g. 9). These speclinens, with densitied far below theoretical values, failed in the threade of the tensile teat apecimens.

Utilizing hydrogen for the complete cycle resulted in elgniflcently lower strength values, large gralns, and 10 hardnese values. Surtching from byarogen to argon at $1300^{\circ} \mathrm{C}$ during the carly part of the standard cycle resulted in increased ductility, but lower yleld strength. minination of the 2-h bold at $1300^{\circ} \mathrm{C}$ during heat up ylelsed a decrease in grath stee and algotricant decreunes in ultimate tewalie otxength and longation. Bilutinating this peupe precluded wah of the oolid-ctate alntering in the menclel before 11quid phese tranoport. A 1-b eubeticution at $1400^{\circ} \mathrm{C}$ for the standard $2-\mathrm{b}$ at $1300^{\circ} \mathrm{C}$ decreased the yleld atrongth allobtly, but coulted in a slenir1cant increase in elongntion and reluction in gonin ase.

W1th opeciwen made with the conres tungaten powder, ancels in argon or vacuin appenred to decrsase yleld atrength ellgitly, lut increased the ductility with no eppenreat offect on grain ofre. With the fine tungeten euples, hovever, no improvewont we noted on tho already cacallent ductility of the standard fine tungoten comple. Increases in graln else wore noted. The 8-b argon treaturnt did seam to Incresse the tungaten particlo-to-particle Jolning. Witb the fine tungoten arries afntered et $1510^{\circ} \mathrm{C}$ for $30 \mathrm{mdn}$, the 4-h vacum anneal helped properile mrkedly, malfesting elfoirlcant increanes in strenigth and elongation. Vacul annealing the anples ade vith intermodiate tungoten powder had no effect on ductility, but did result in in increased ultimte tensile atrength.

The experimental verintions that mot arfected. the microstructure and properties were additives to the binder phuse. sadstions of $\mathrm{2r}, \mathrm{Fr}, \mathrm{mog}_{2}$, and TwC vere deleteriou to poperties benexnly, although this weint be wleleading becane the Intericl produced did not approech theoreticiel dematty. Microstructures of the recultent aterini are chown as follows: ThC adations a equile F-1520-9 (I1R. 7), hernim adition as ariple C-1520-26 (FIB. 10), and $\mathrm{ThO}_{2}$ addition an anple c-1520-27 (Hg. 10). The merostructure of the interial with zirconium additions in not ahown becense it appeared -inilar to the standard steridi... Wo boped thut the eirconium or hrmiur addition fint atrongtbm the binder phase tlirough an alloying or conpond forming process. The $\mathrm{ThO}_{2}$ and $\mathrm{Tac}$ adattion were enticipated to provide a diffaraton atrengthening effect. Wtber these inpoverente ware not anifeated or the orfect we molved by the 10 s danaltied obtalned in the ntericls. Furtber investientions 


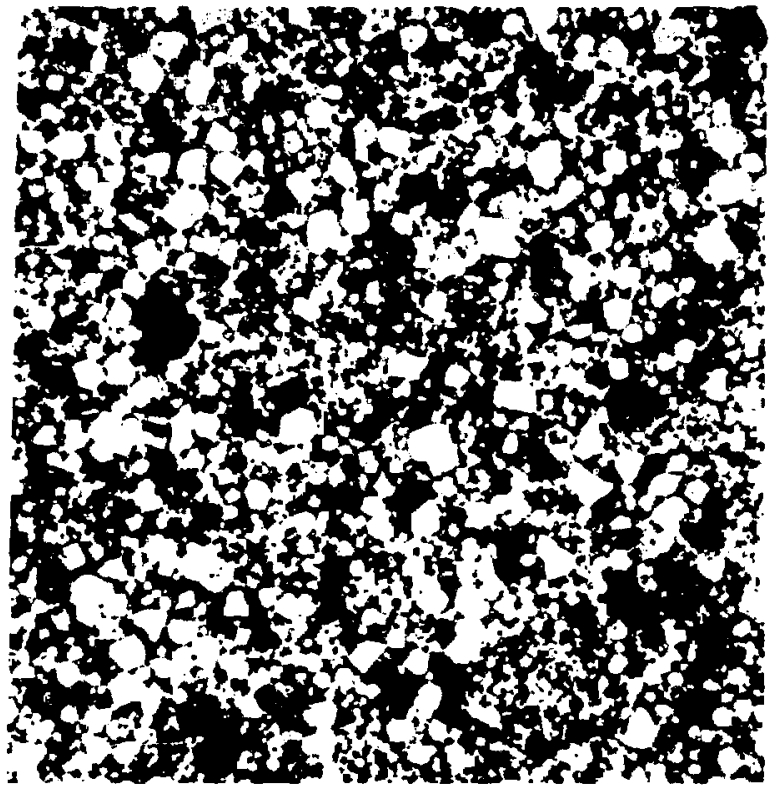

$250 x$

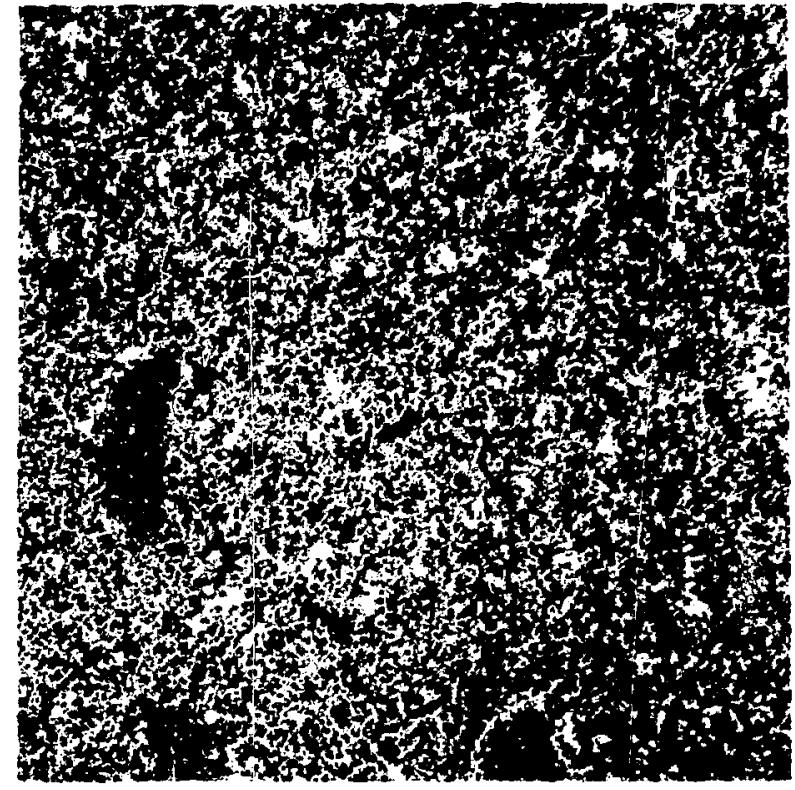

$250 x$

Mine standard

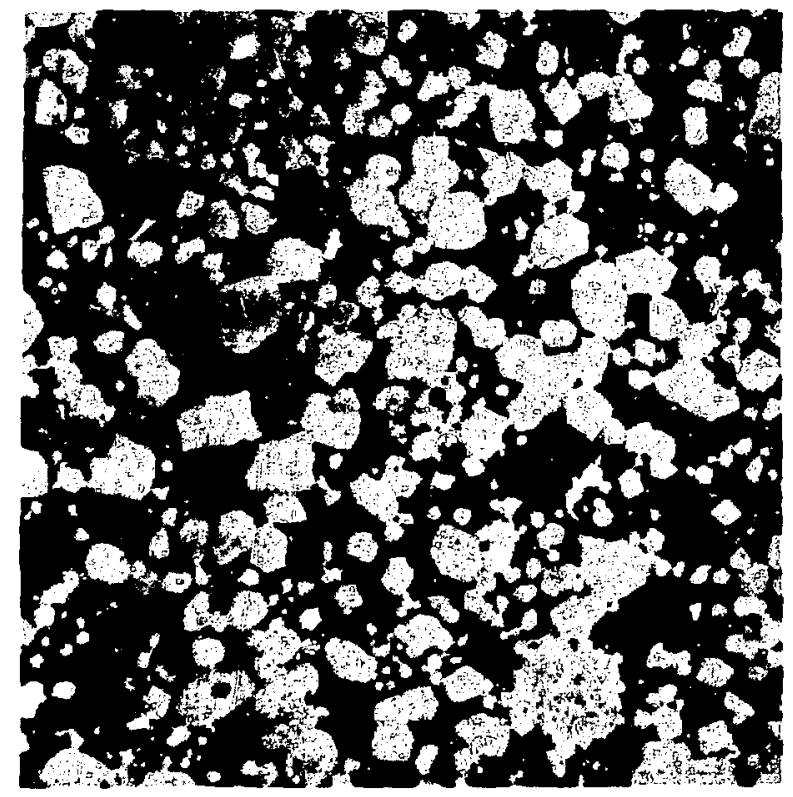

$500 x$

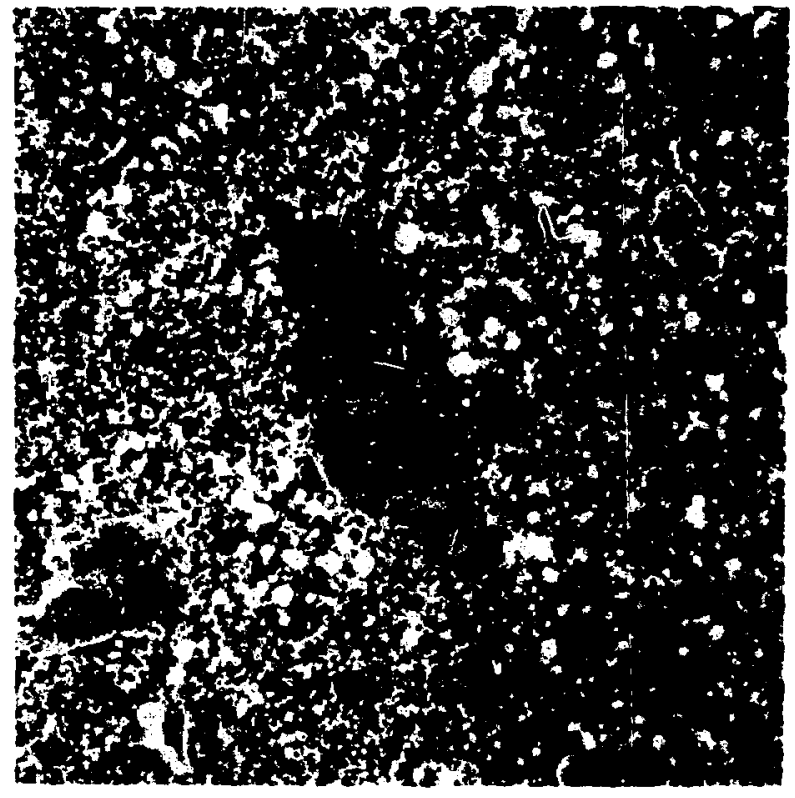

$500 x$ 


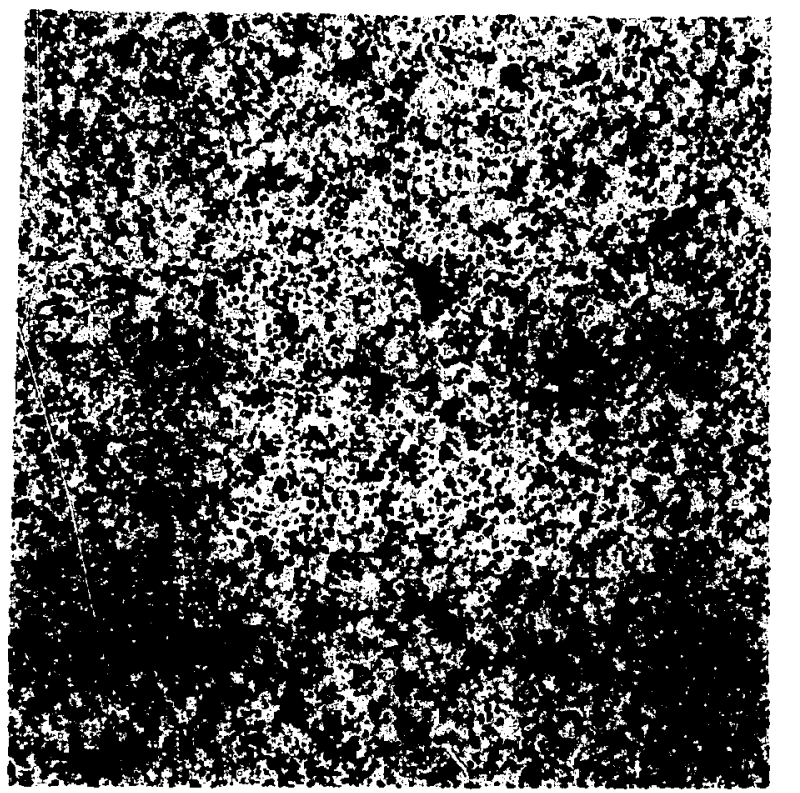

$200 x$
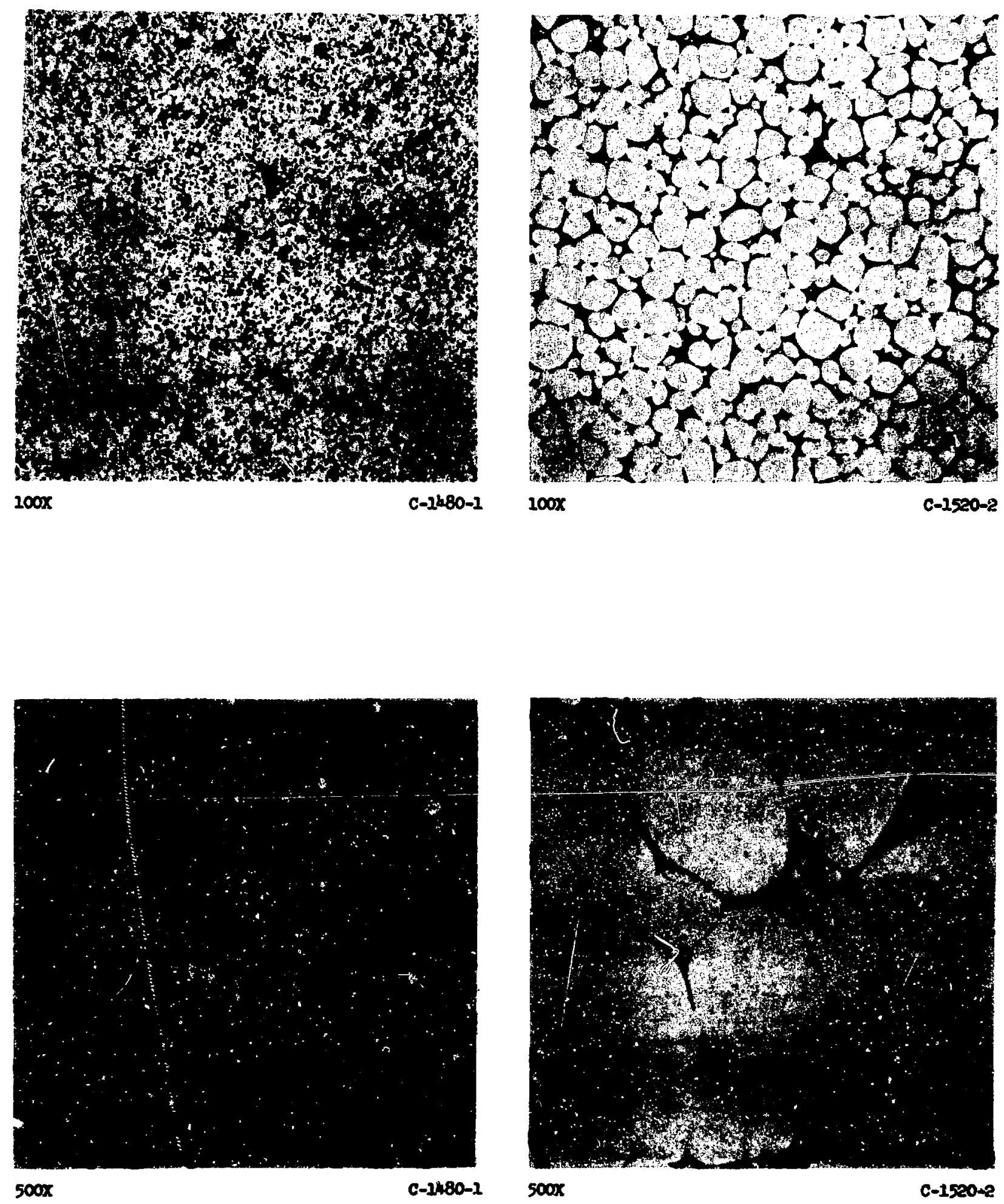

F8. 6. Herostructure of $N-\pi 1-F e$ alloy of atandard compaltion. 


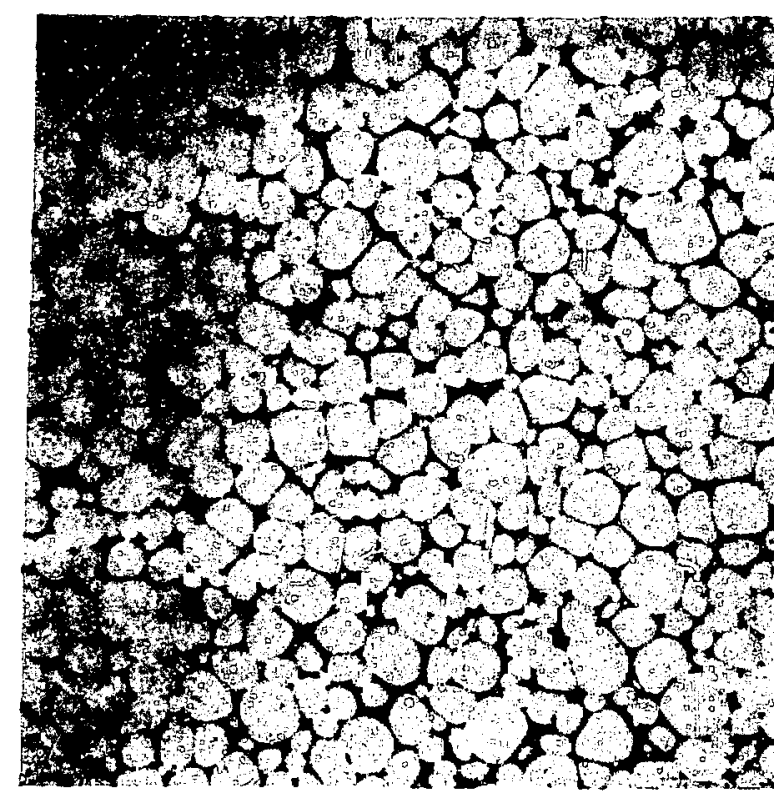

$100 x$

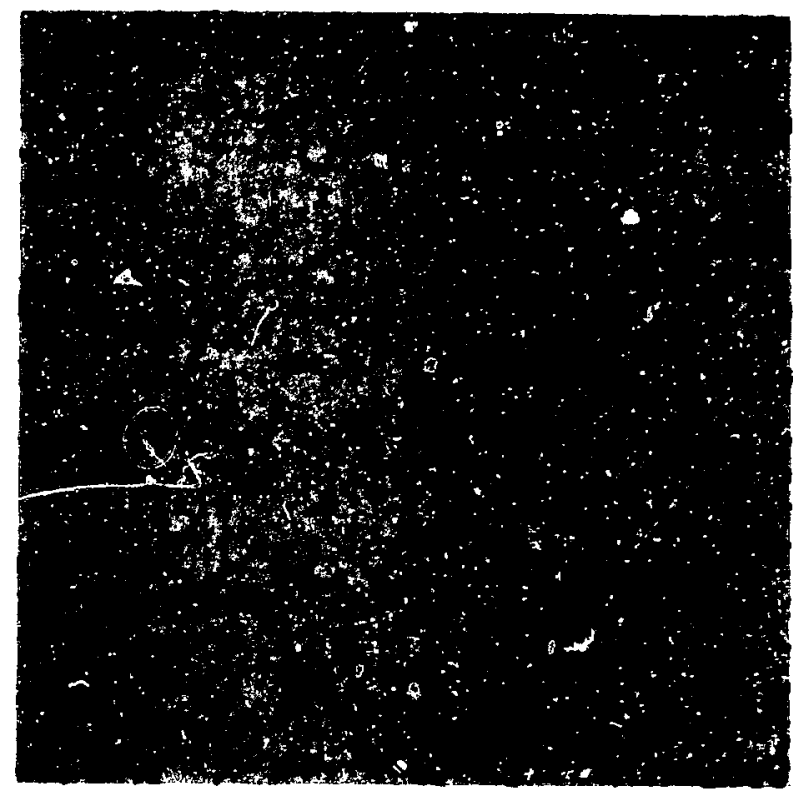

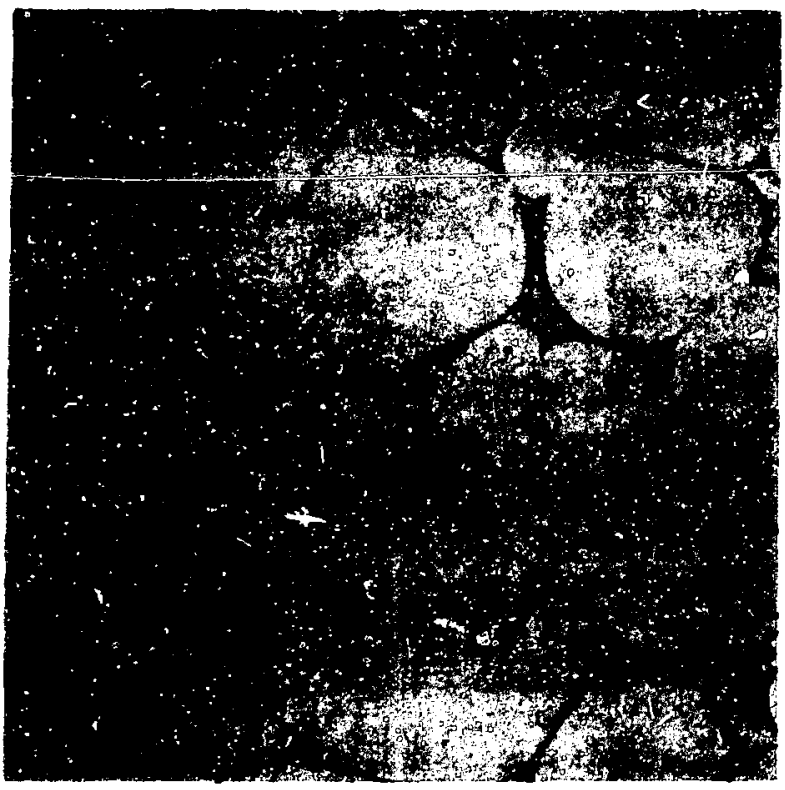

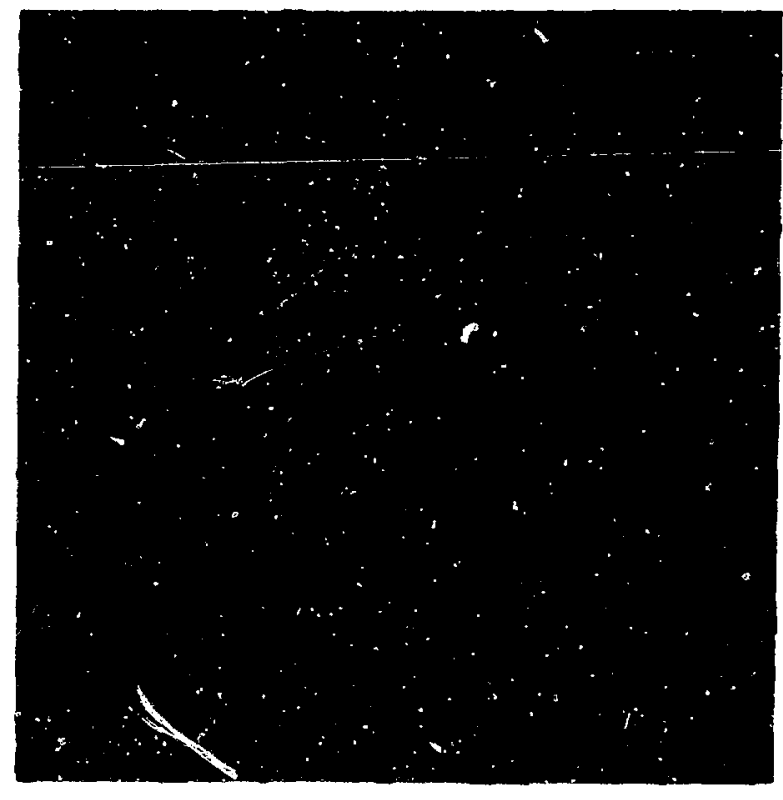

$500 x$

F18. 7. Herostructure of Y-WI-Fe alloye of atandard compostion (left) and with Tac additions (right). 

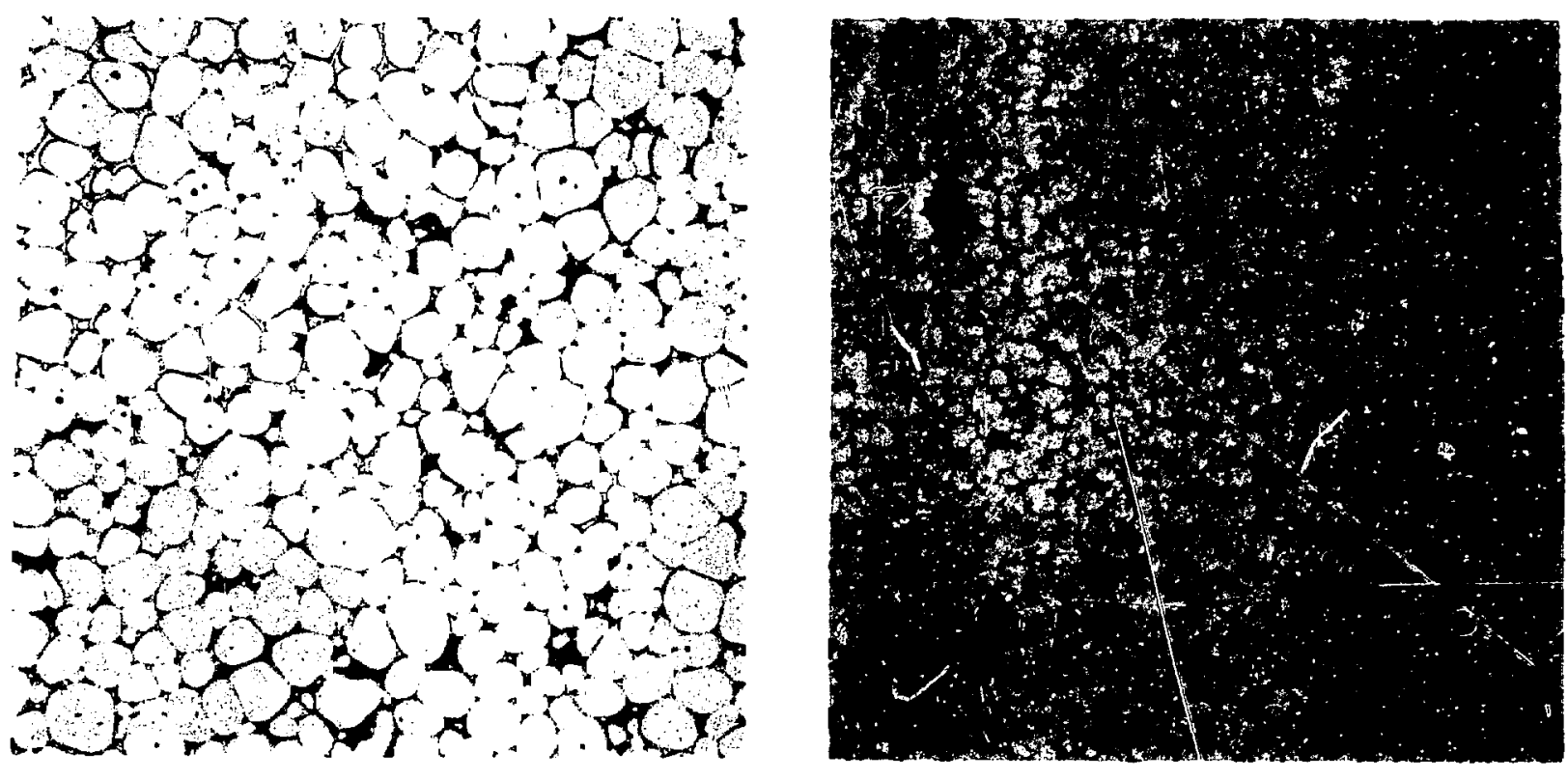

$100 x$

I-1500-4

$100 x$

$I-1500-6$
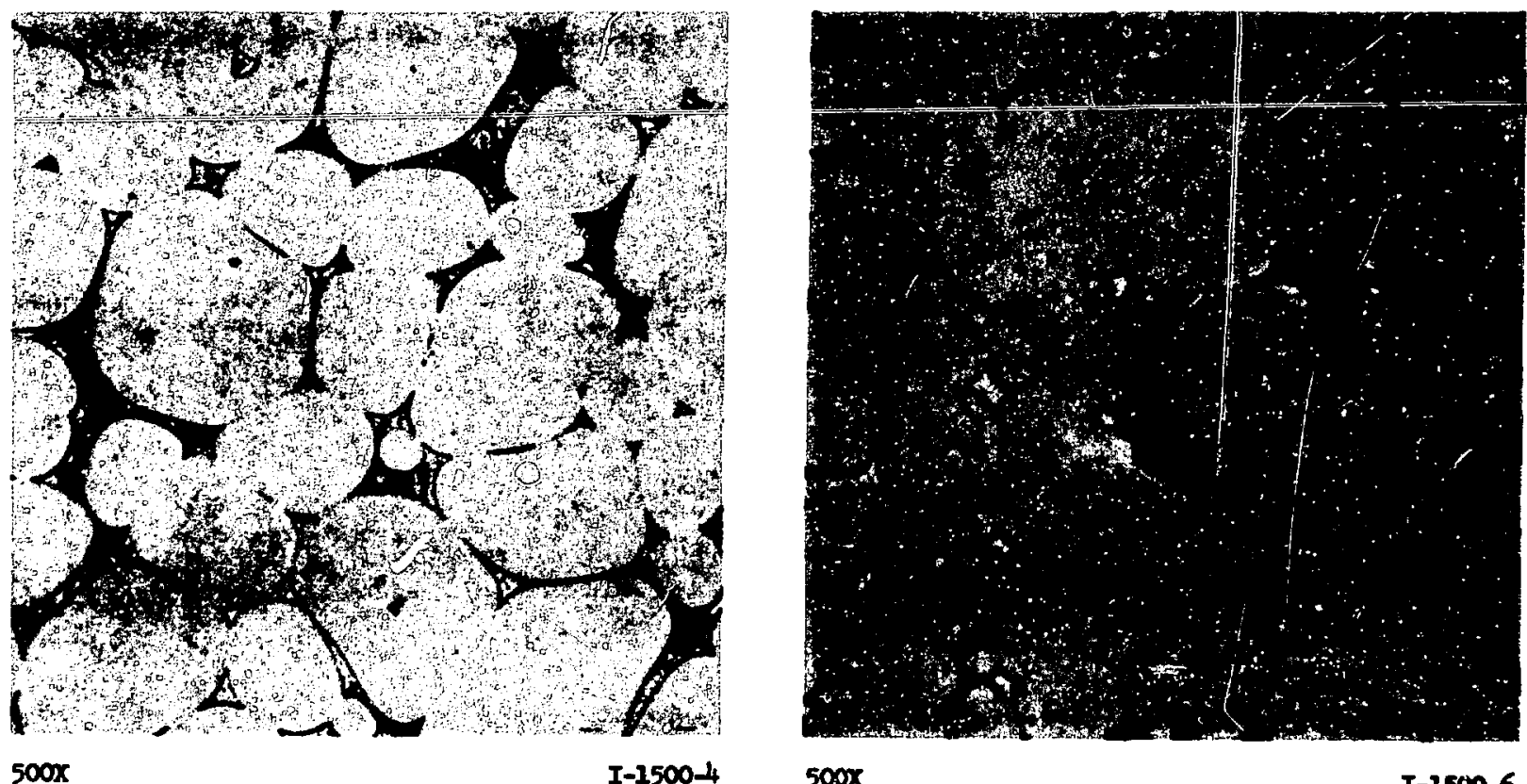

FHB. 8. Herostrunture of W-MH-Fe Noys of standerd composition (Iort) and with chroniun additions (riegt). 


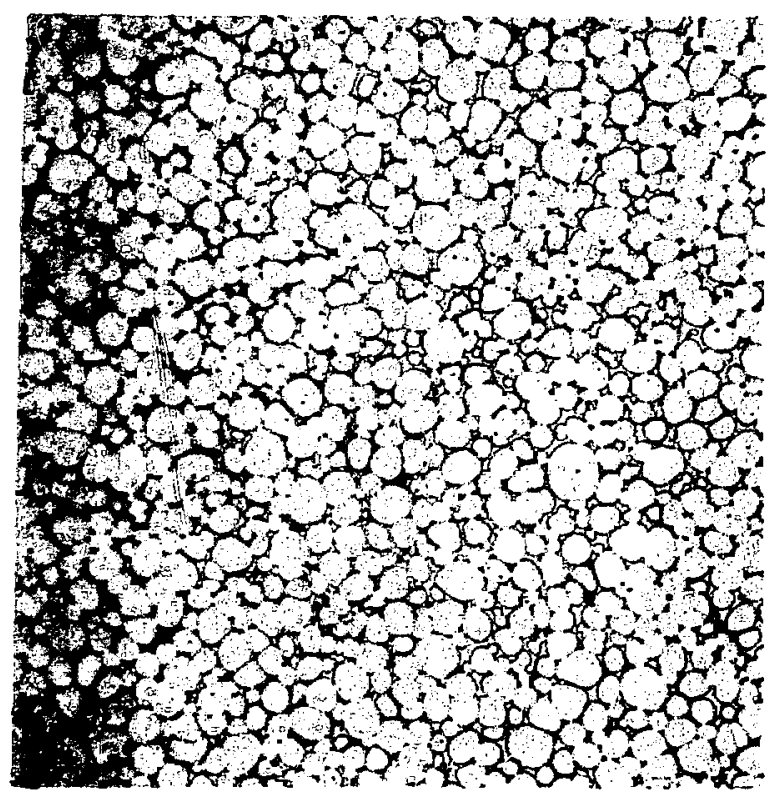

$100 x$

\section{P-1510-1}

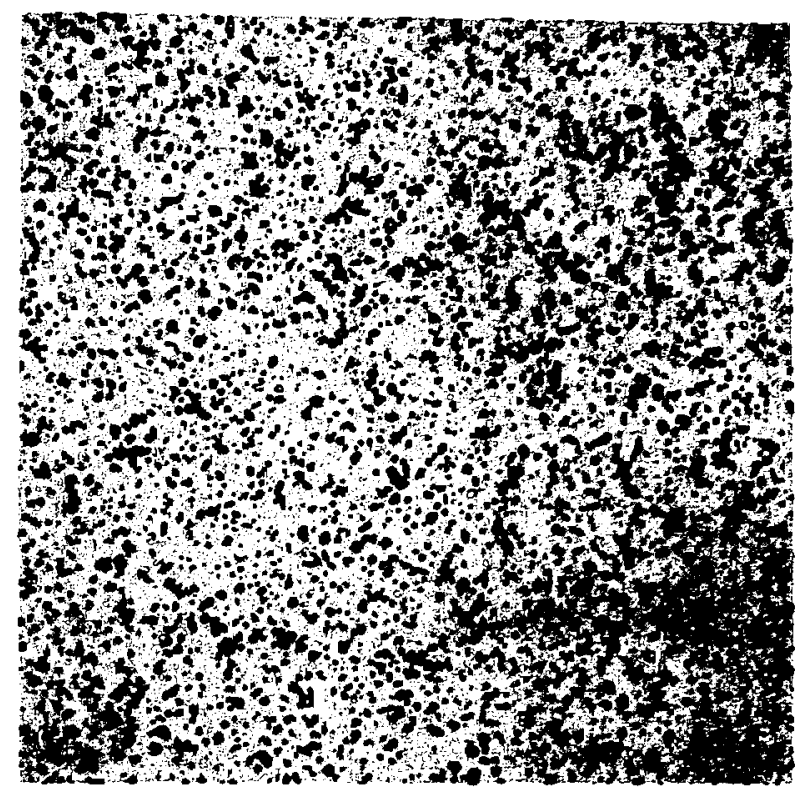
$100 x$

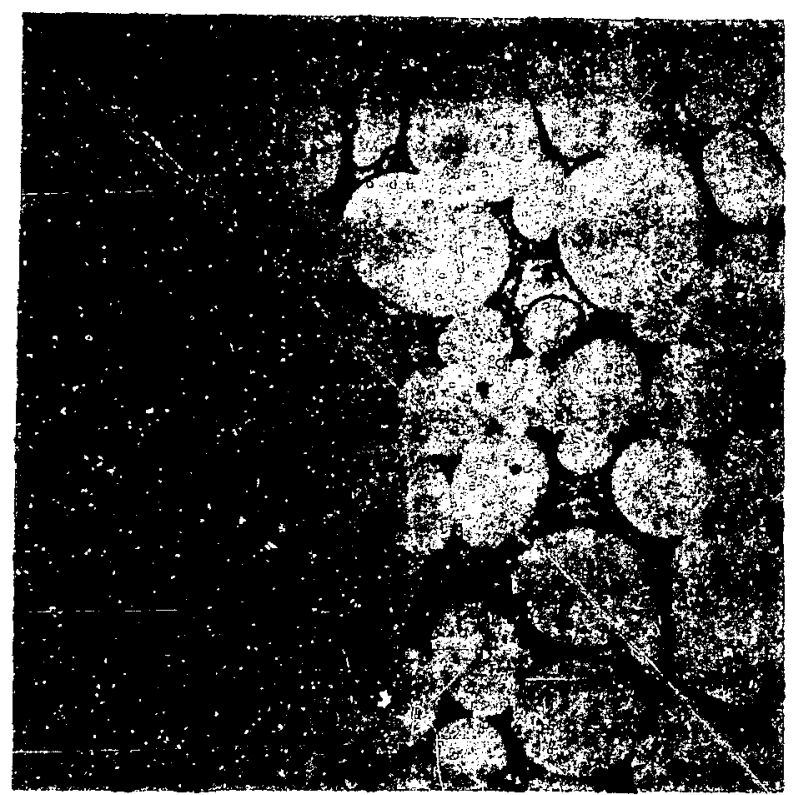

$500 x$

F-1510-1

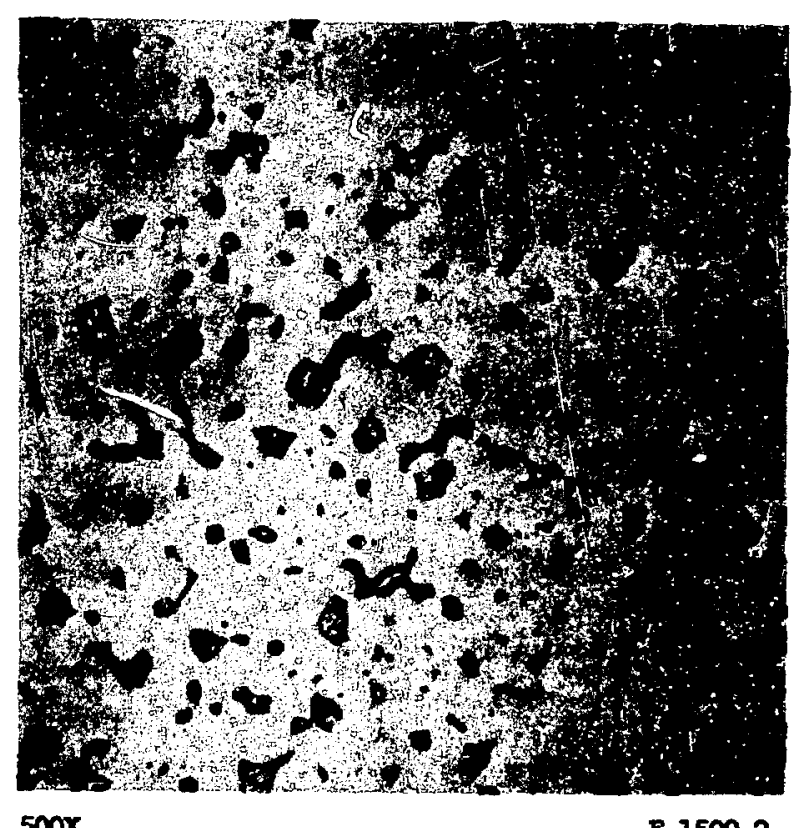

$500 x$

$F-1500-2$

F18. 9. Microtructure of W-NH-Fe alloys of atandard compeition. 

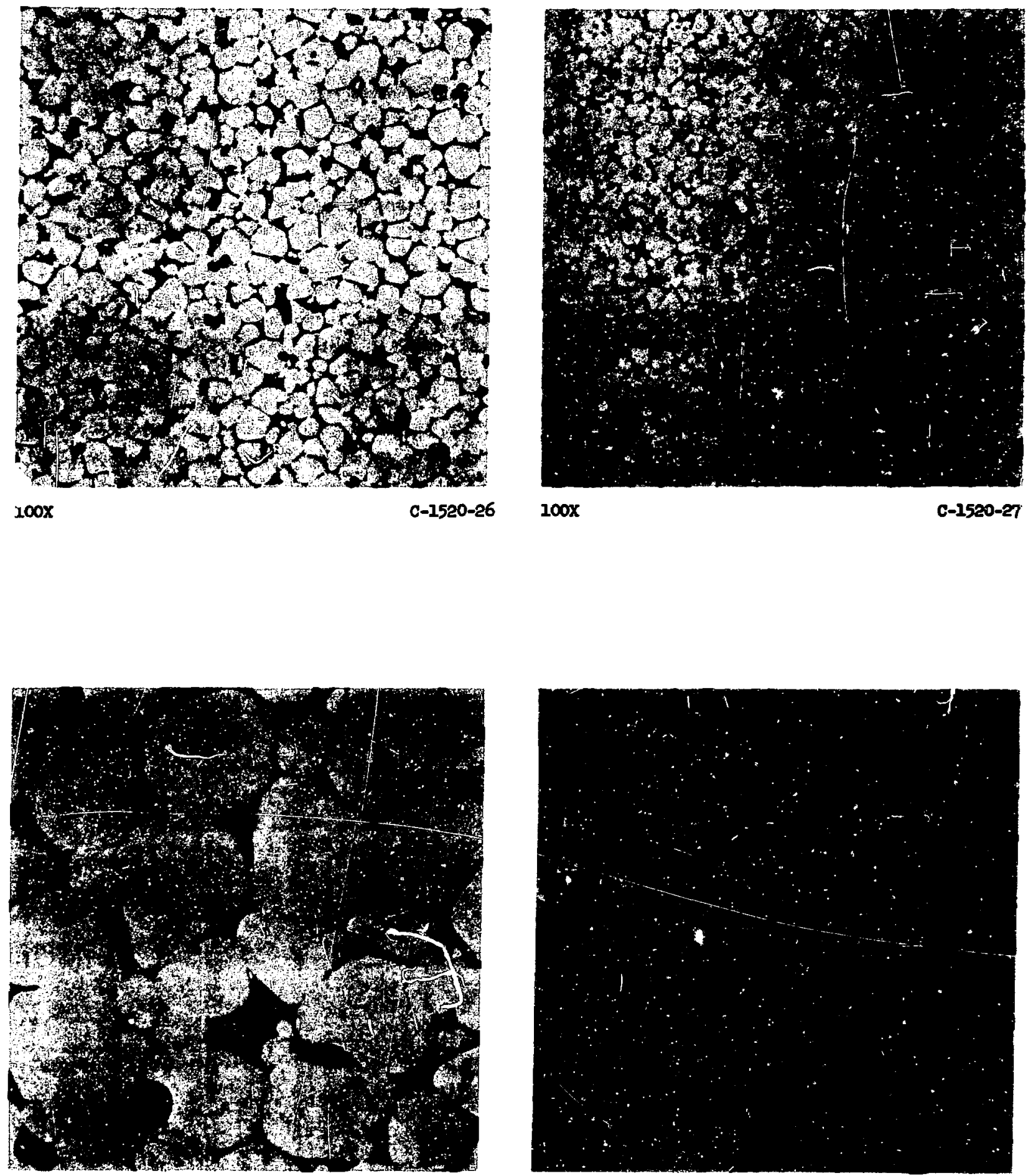

$500 x$

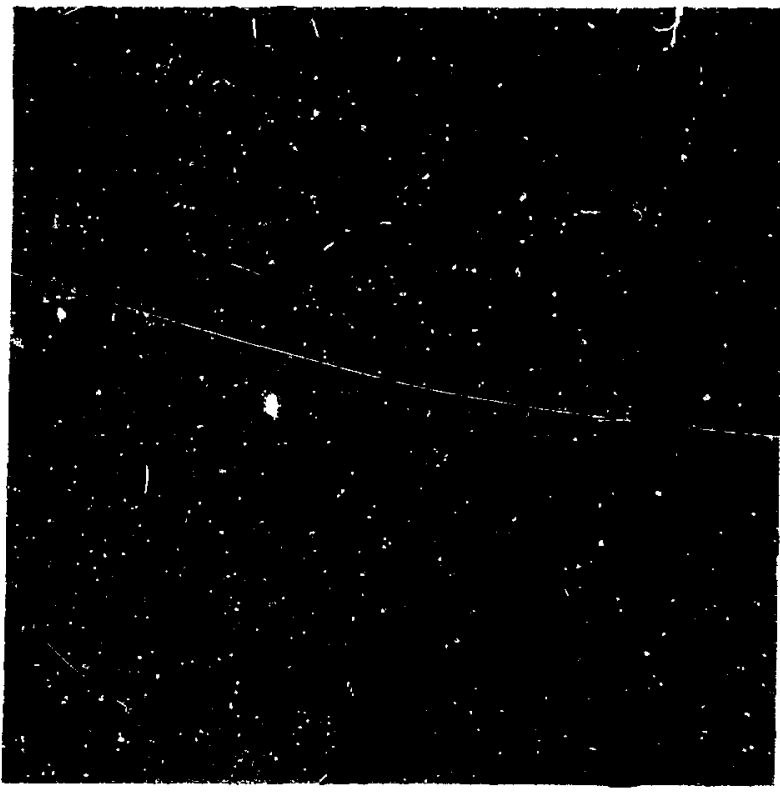

F18. 10. Mlerostructure of W-n1-Fe alloys with hafnium additions (lort) or $\mathrm{ThO}_{2}$ additione ( $\mathrm{r}$ ght). 
of alntering schedules would te necessary to deterwine the correct combination for obtaining denae raterial.

Adilitione of chromiun yielded sose succeas in etrengthening the material. The maller addition. increased the ultiate tensile strength and elongation, and kept the grain size amall, but were detrimental to the yleld strength. Higher chroulum adattions, however, Ied to an incraase in the ult,1mate tenulle strength, yleld strength, and hariness by agnin keeping the grain size amall. Microstructure of the material with the higher chroutim additions is ahown in aemple I-1500-6 of Fig. 8.

The rhenium addition abowed the noat arked effect of any additive. Hoperully, the rhenium addition would strengthen the matrix phace and toughen the tungsten particles. As seen in Flg. 1 , the wicrostructure obtained was entirely different from that of the standard structure. The material with the rhenium addtion exhibited the highest strengthe, greatest haxdness, and mallest crain size of any material tested, but had less ductility.

A Cr-FI-Fe alloy was used as a binder meterial In specinen C-1520-34. The photonicrogragh in Fis. 11 whows that sowe of the tungsten grains had a fuszy texture, the cause of shich is unknown. Properties were poorer than those of the standard, but again the density was not near theoretical. Inso apecion was aintered for 1 h at 1520, 1540, and $1560^{\circ} \mathrm{C}$ in an efrort to improve the density. Sowe impovement was efrectod, but we felt that further atterpta at denalfication were not marranted.

In anplen C-1460-18 and C-1460-19, the coarae tungaten poider wa plated with nickel in an attermpt to ensure good diatribution and to provide a coherent diffurion path for the tuncaten. Nithough the ultimate tenalle atrength and elongation were dintiniabed, the yleld atrength was alenifleantly higher than that of the atandard.

It appears that with these alloys the DFH sardnese muber is a cood indicator of relative value of the yield atrength.

vI. SUCGESTIONS FOR FUIURE WORK

From information gathered in this investigation It appeare that rurther atudy of the W-li-Fe alloy syater, incorporating into the arated some or all of the benericiel variation observed here, would be userul. Some promining variations are (a) substituting a $1-\mathrm{h}$ hold at $1400^{\circ} \mathrm{C}$ for the previously used $2-\mathrm{h}$ hold at $1300^{\circ} \mathrm{C}$, (b) utillsing fine tungsten poider, (c) vacune annealing, (d) anll additione of rhention or chrowiun, and (e) nickel plating the tungaten powders.

in interesting facet for ruture irvestigations would be to utilize the electron microprobe to derecmine the chemiatry wis the binder phase, and the compositicial gradients existing between the tungaten grain-matrix interface and the bull of the matrix material.

St1Il asiother area for inveotigation would be poselble attaupts to toughen the tungsten grain as well as to strengthen the matrix.

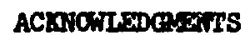

This work was performed with the support of J. M. Twub. The authoro are Indebted to LASL Group CXB-1 for the chendenl analysis of the pouder; to T. I. Jones and C. A. Javoraky of the CXB-6 Fuys1cal ketallurgy section for conventional metallography, tensile and neaure testa, and graln size deteridnation; to John Kagmueon for pouder charecter1atice deternitiation; to secundino sundoval for the iluntrutions; to the CVB-6 Plastics section for making the plastisol ancks; to John Kostacopoulos for imersion densities; to the CAB-6 Blectrochem1stry Section for plating of tungaten powders; to the Shop Degartment for anples mahining; and to B. K. Richerson for eintering.

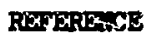

1. R. H. Krock, "Solld State Sintering and Particle Growth in W-H1-Fe composites," Proc. Am. Soc. Testing rater. 64, 669-680 (1954). 

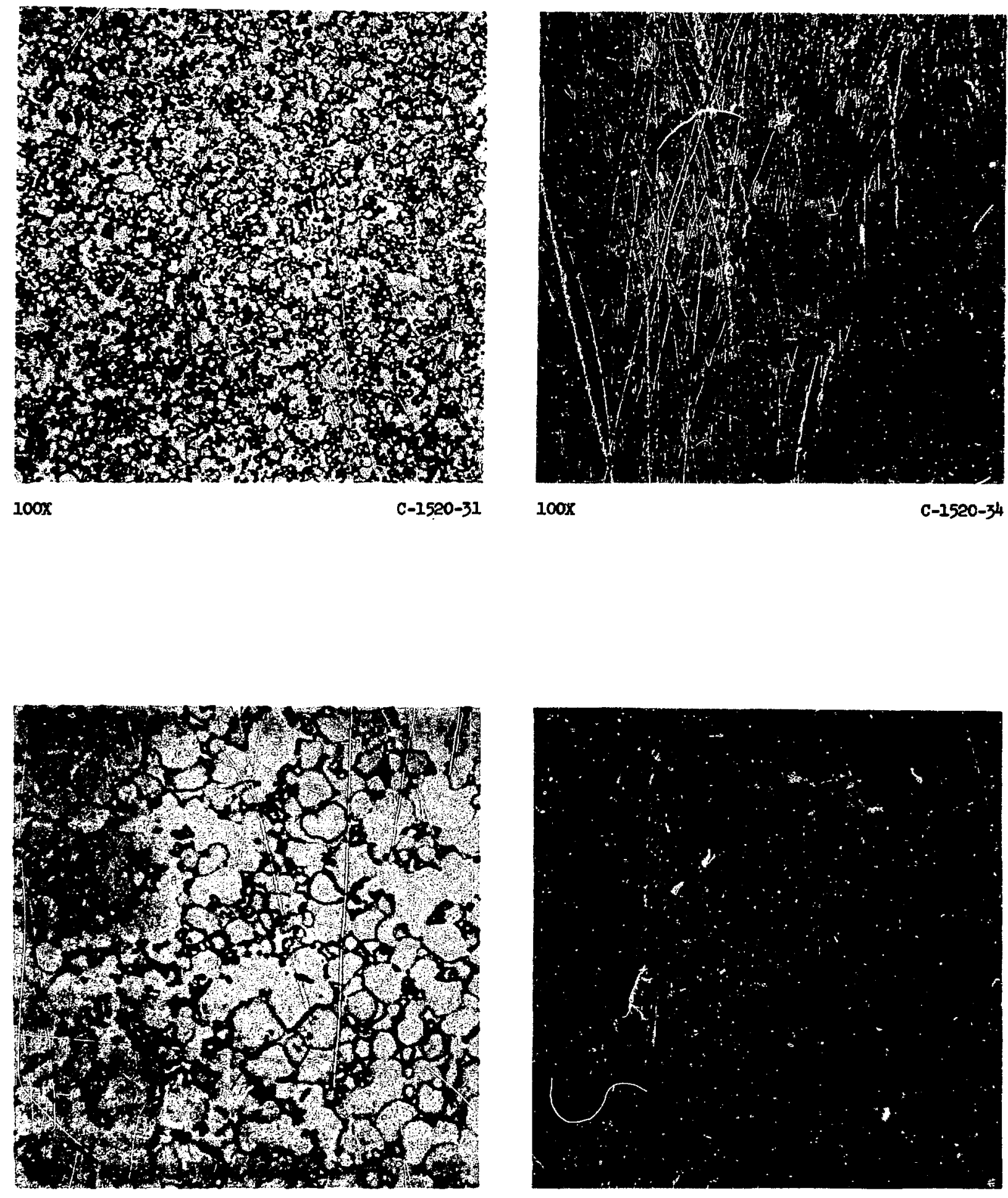

F18. 11. Microstructure of W-NI-Fe alloys with rhenium ociditions (lert) and $\mathrm{Cr}-\mathrm{NI}-\mathrm{Fe}$ alloy additions (right). 